УДК 377.014.61-047.36

DOI https://doi.org/10.33989/2519-8254.2019.6.205788

ORCID https://orcid.org/ 0000-0002-1801-9709

ORCID https://orchid.org/0000-0002-9742-5827

\title{
ORGANIZATION OF MONITORING RESEARCH ON THE QUALITY OF EDUCATION IN VOCATIONAL (VOCATIONAL AND TECHNICAL) EDUCATIONAL INSTITUTIONS
}

\section{Liudmyla Beberina Ihor Savenko}

У статті розглянуто актуальні питання сучасного стану розвитку системи професійної освіти Украӥнської держави в умовах євроінтеграчії. Важливим завданням підготовки висококваліфікованих фахівиів визначено отримання повної та об'єктивної інформації про стан навчання. У зв'язку з ичи актуалізовано проблему моніторингу в освітній галузі, зокрема - моніторингу якості професійної підготовки випускників професійних (професійно-технічних) навчальних закладів.

Акцентовано, щуо для забезпечення якості професійної (професійно-технічної) освіти в сучасних умовах важливо розробити систему внутрішнього оцінювання якості освіти в професійних (професійно-технічних) навчальних закладах, яке має спрямовуватися на оцінювання якості освіти за показниками кінщевого результату діяльності навчальних закладів, а саме: професійної підготовки майбутніх кваліфікованих робітників. Оцінювання професійної підготовки випускників професійних (професійно-технічних) навчальних закладів пропоновано здійснювати через моніторинг n'яти ї̈ складових (інтелектуальної, діяльнісної, комунікативної, рефлексивної, професійно важливих якостей). Обробку моніторингових даних пропоновано проводити на основі кваліметричного підходу з використанням факторно-критеріальних моделей. Перспективу подальших досліджень спрямовано на визначення організачійно-педагогічних умов проведення моніторингу якості освіти у професійних (професійно-технічних) навчальних закладах.

Ключові слова: заклади професійної (професійно-технічної) освіти, кваліметрична модель, кваліфіковані робітники, моніторинг, навчальна діяльність, оцінювання якості освіти, професійна підготовка.

Ukraine's European integration requires attention to the quality of education in general, and, in particular, to the quality of training of qualified workers in vocational (vocational technical) educational institutions. Today, with the active introduction of information technologies in all sectors of the economy and the rapid growth of scientific and technological progress, the issue of providing qualified educational services is becoming increasingly crucial and plays an important role in the strategic policy of our country. In 2-4 years, professional knowledge will become obsolete and this fact requires modernization of educational standards, focusing on the professions of broad qualifications and training a competent specialist who has such qualities as sociability, ability to adapt to today's needs, to make creative decisions, to teamwork and to take on self-responsibility.

Monitoring of the teachers' educational activities and students' academic achievements is one of the stages of improving the quality of education. Among the list of strategic directions of education development, in accordance with the National Strategy for Education Development in Ukraine for 2012 - 2021, there is an issue of ensuring national monitoring of the education system [7, p. 3]. The information about the real state of the educational process could be 
received due to the education monitoring system and the conclusions about the quality of education in general could be made.

More and more attention is paid to the training of a competitive worker in our country, which directly depends on the quality of educational services. The problem of providing a highquality education is acute in vocational (technical) educational institutions today, and the use of modern methods of monitoring the quality of education is one of the components of solving this problem. The monitoring the teachers' educational activities or students' educational achievements can be considered here.

Formulation of the problem. The quality of vocational education in Ukraine does not fully meet today's requirements. This issue can be addressed when gaps in the provision of vocational training services are well known. The monitoring research can influence the objective and reliable picture of the real state of the quality of education in vocational (technical) educational institutions possible.

Analysis of publications on the selected issue shows that monitoring the quality of education has been studied in several areas, including: the formation of the concept was determined by V. Bespalko and I. Havrylenko, monitoring technologies were developed by A. Yermola and I. Bulakh; monitoring as a means of assessing the quality of education is studied by V. Kalnei and N. Mykhailova; A. Halahan, A. Saveliev, V. Kachermanian, L. Semushyna analyzed in their works the increase of efficiency of professional education development; O. Maiorov, N. Selezniova, L. Semushyna, and R. Shyshov described the theory and methodology of monitoring in their research.; A. Bahirov, Yu. Branovskyi, T. Vorontsova, L. Kalinina and many others considered the use of information and communication technologies in monitoring the quality of education.

But the issue of monitoring the quality of professional competencies of graduates of vocational (technical) educational institutions is still not thoroughly studied and needs further research.

The purpose and objectives of this article is to determine the mechanisms for monitoring the quality of education in vocational (technical vocational) educational institutions and to prove the need for monitoring as a component of training future qualified workers.

Presenting main information scope. The term "monitoring” does not have a single interpretation, in the general sense it is the observation of any object or phenomenon. Scientists interpret monitoring of the quality of education in general as a system of systematic control, collection and processing of information to assess the quality of the educational system, to identify shortcomings, to make appropriate management decisions in order to create optimal conditions for providing quality educational services. For example, T.A. Stefanovska gives the following definition: "Diagnosis, assessment and forecasting of the pedagogical process: tracking its progress, results, prospects" [9, p. 18]. S.Ye. Shyshov treats monitoring in education as "a set of continuous control actions that allow you to observe and adjust the need to move the student from ignorance to knowledge" [10, p.135]. O.M. Maiorov defines that "Monitoring in education is a system of collecting, processing, storing and disseminating information about the educational system or its individual elements, which is focused on information management, allows to draw conclusions about the state of the object at any time and gives a forecast of its development" [6, p.154].

In the Encyclopedia of Education, monitoring in education (Latin monitor - one that reminds, supervises, stores) is considered as a special system of collecting, processing, storing and disseminating information about the state of education, forecasting based on objective data of dynamics and main trends and development of scientifically grounded recommendations for management decisions in order to improve the efficiency of the educational sector [4, p. 519]. 
Thus, considering the definition of "monitoring the quality of education" quality in the system of vocational education could be considered. It should be noted that in the context of vocational training for the concept of "quality of education" it is impossible to give a complete and comprehensive interpretation. It is rather a social construction, the interpretation of which depends on the values, goals, resources of stakeholders, as well as on the general context. Thus, the European Center for the Development of Vocational Education and Training (CEDEFOP) in its "Glossary on Quality in Education and Training" provides the following definition of quality: "the degree to which the available characteristics meet the requirements." It follows that under different conditions or for different stakeholders, this concept may have different meanings. The reason is simple: because of certain characteristics it has more or less weight for different subjects. In addition, the understanding of the concept of quality may change (and is changing) over time as the context of vocational education changes. Accordingly, different systems may have different perceptions of quality. In the vocational education system, quality is sometimes expressed in the understanding of standards (professional standards, qualification standards, educational standards, vocational education and training standards), ie. the set of knowledge, skills and abilities that a person must possess to perform a particular profession or function. Thus, quality assurance is an effort to ensure that the system and its participants (namely vocational schools and colleges) can provide services that meet these standards on an ongoing basis [5, p. 2].

In order to talk about the effectiveness of monitoring of vocational education in an educational institution, during its implementation it is necessary to ensure certain conditions: objective assessment, validity, reliability, systematicity, humanism.

All monitoring functions contribute to improving the efficiency of vocational education institutions and are aimed at improving the efficiency of the training and production process. Though, it can be concluded that monitoring the quality of vocational education is one of the main criteria for the effective functioning of vocational education.

The main areas of monitoring of education in vocational (technical vocational) educational institutions can be identified:

- educational monitoring;

- monitoring the educational needs of students;

- professional monitoring (observation of the development of the pedagogical process of specialists' training);

- monitoring the level of socialization of the individual;

- monitoring the health of students;

- pedagogical monitoring.

Monitoring the quality of vocational education can be done at several levels:

- the level of the cycle commission;

- level of professional orientation;

- level of educational institution;

- regional level;

- $\quad$ state level.

Practical implementation of monitoring tasks by the institution of professional (vocational education) is carried out at the next levels. At the level of the cycle commission, it is expedient to use monitoring of educational needs of students, monitoring of the level of socialization of the individual, monitoring of the health state of students, subject and pedagogical monitoring. At the level of professional orientation, it is expedient to use monitoring of educational needs of students, monitoring of the level of socialization of personality, monitoring of students' health, pedagogical monitoring, professional monitoring, educational monitoring, at the level of educational institution - educational monitoring. 
The indicators of monitoring the results at the level of the cycle commission include key competencies of graduates, the level of adaptation of graduates in society; the level of sociability of graduates of the educational institution, connections between colleagues.

Among the indicators of monitoring the results at the level of professional orientation can be distinguished: professional orientation of graduates, professional competence of graduates, and compliance of the level of knowledge and skills with professional requirements.

The indicators of monitoring the results of the educational institution include: the place of the educational institution among other institutions of vocational (technical) education, the number of entrants who want to study in this educational institution, graduates' employment within the specialty, graduates' readiness for professional activity, graduates' salary level.

Therefore, as an example of the organization of monitoring research, the following stages of monitoring could be highlighted.

The first stage is preparation. It is necessary to form the purpose and determine the object of research, to find out the terms of monitoring and research procedure, to study the necessary literature, to study the available pedagogical experience on this issue and to develop tools for monitoring: to determine evaluation criteria and indicators depending on objects; to develop and examine various tests and questionnaires, to analyze research methods, to develop regulations and instructions for professionals who will monitor the quality of education in school.

The second stage is practical. There is data collection, observation, interviews, testing, questionnaires, attendance, etc.

The third stage is analytical. Here is the generalization of statistical information, systematization of the results and analysis of available data. At this stage, it is necessary to draw conclusions and develop recommendations for further action. At this stage, we can talk about forecasting the development of the educational process in the institution.

Thus, the correct organization of monitoring of educational activities contributes to the better functioning of the educational institutions, the management performs the necessary control decisions, makes certain adjustments to the educational and production process, to the teaching staff, that is the ability to plan educational work, to create an optimal educational environment.

According to the National Strategy for the Development of Education in Ukraine for 2012-2021 "The effectiveness of the management of the education sector largely depends on how sensitive the system of monitoring and evaluating the quality of education is to the goals and objectives of the state educational policy of Ukraine and how management decisions are adequate to the results and recommendations of monitoring research.” Promising areas for monitoring and evaluating the quality of education in Ukraine should be:

development of the Concept of the national system of monitoring and evaluation of the quality of education;

conducting fundamental research in the field of methodology of pedagogical measurements, evaluation of the effectiveness of educational policy; development of a model for monitoring research for different levels of government (intra-school, regional, national);

- development of a system of indicators of quality of education at the national level, which reflects the conditions, processes and educational outcomes;

- $\quad$ monitoring the quality of resource provision, educational processes and results;

- $\quad$ participation in international comparative studies of the quality of education (TIMSS, PISA, PIRLS, etc.);

- $\quad$ creation of an extensive network of regional centers for monitoring the quality of education; modernization and upgrading of the system of educational statistics; 
- $\quad$ providing the population, government agencies, educational institutions with reliable information on the conditions and effectiveness of the educational sector at its various levels;

- $\quad$ publication of the results of monitoring the education system, in particular by means of ICT [7 p. 33].

promoting the functioning of internal quality assurance systems for the provision of educational services in vocational (technical) educational institutions through the implementation of advisory and information activities by the National Agency for Quality Assurance in Education;

- monitoring the activities of vocational (technical) education institutions by the National Agency for Quality Assurance in Education through accreditation procedures.

Conclusions. The desire to achieve high educational results in institutions of vocational (technical) education encourages all participants in the educational process to look for ways to implement it. One such way is to monitor the quality of education, which allows you to collect, store, process, and disseminate information about the activities of the educational institution. But today in the system of vocational education monitoring is a relatively new phenomenon, which is only being introduced and gradually improved. Monitoring studies can be conducted for various purposes, but in any case they will lead to the accumulation of information about the functioning of the educational institution, the ability to monitor the results of the educational process and predict the development of the educational process in the educational institutions.

Prospects for further development are to determine the pedagogical conditions for monitoring the quality of education in vocational (technical) education, improving the technology and tools for monitoring the quality of education in terms of facilities of vocational (technical vocational) education.

\section{ЛІТЕРАТУРА}

Азізова, К. (2016). Етапи моніторингу якості освіти у вищому навчальному закладі. $B u$ токи педагогічної майстерності, 17, 3-12. Взято 3 http://dspace.pnpu.edu.ua/handle/123456789/7557.

Бодненко, Д. М., Жильцов О. Б., Лещинський О. Л., Мазур Н. П. (2014). Моніторинг навчальної діяльності: навч. посіб. Київ: Київ. ун-т імені Бориса Грінченка.

Волок, В. В. (2016). Предметний моніторинг як засіб підвищення результативності навчальної діяльності учнів в системі роботи методичного об'єднання. В кн. М. І. Романенко (Ред.), Роль навчальних моніторингів у формуванні всебічно розвиненої особистості учасника навчально-виховного процесу: матеріали обласної наук.-практ. конф. 26 жовт. 2016 р. (с. 80-84). Дніпро.

Кремень, В. Г. (Ред.). (2008). Енциклопедія освіти Академія пед.наук України. Київ: Юрінком Інтер.

Забезпечення якості у системі професійної освіти $i$ навчання. Взято 3 http://ipq.org.ua/upload/files/files/03_Novyny/2015.03.18_Twinning_final_conference/ Quality\%20assurance-\%20UKR\%20.pdf.

Майоров, А. Н. (2005). Мониторинг в образовании. Изд. 3-е, испр. и доп. Москва: Интеллект-Центр.

Національна стратегія розвитку освіти в Україні на 2012-2021 роки. Взято 3 http://oneu.edu.ua/wp-content/uploads/2017/11/nsro_1221.pdf.

Скубашевська, О. (2008). Моніторинг якості освіти: поняття та реальність здійснення. Вищза освіта України, 3, 37-42.

Стефановская, Т. А. (1998). Педагогика: наука и искусство: курс лекций: учеб. пособ. для студ., преподавателей, аспирантов. Москва: Совершенство. 
Шишов, С. Е., Кальней, В. А. (2000). Школа: мониторинг качества образования. Изд. 3-е, исп. и доп. Москва: Педагогическое общество России.

\section{REFERENCES}

Azizova, K. (2016). Etapy monitorynhu yakosti osvity u vyshchomu navchalnomu zakladi [Stages of monitoring the quality of education in higher education]. Vytoky pedahohichnoi maisternosti [The origins of pedagogical skills], 17, 3-12. Retrieved from http://dspace.pnpu.edu.ua/handle/123456789/7557 [in Ukrainian].

Bodnenko, D. M., Zhyltsov O. B., Leshchynskyi O. L., \& Mazur N. P. (2014). Monitorynh navchalnoi diialnosti [Monitoring of educational activities: tutori]: navch. posib. Kyiv: Kyiv. un-t imeni Borysa Hrinchenka [in Ukrainian].

Volok, V. V. (2016). Predmetnyi monitorynh yak zasib pidvyshchennia rezultatyvnosti navchalnoi diialnosti uchniv v systemi roboty metodychnoho ob'iednannia [Subject monitoring as a means of improving the effectiveness of students' learning activities in the system of methodological association]. In M. I. Romanenko (Ed.), Rol navchalnykh monitorynhiv u formuvanni vsebichno roz-vynenoi osobystosti uchasnyka navchalnovykhovnoho protsesu [The role of educational monitoring in the formation of a comprehensively developed personality of the participant of the educational process]: materialy oblasnoi nauk.-prakt. konf. 26 zhovt. 2016 r. (pp. 80-84). Dnipro [in Ukrainian].

Kremen, V. H. (Ed.). (2008). Entsyklopediia osvity Akademiia ped.nauk Ukrainy [Encyclopedia of Education Academy of Pedagogical Sciences of Ukraine]. Kyiv: Yurinkom Inter [in Ukrainian].

Zabezpechennia yakosti u systemi profesiinoi osvity i navchannia [Quality assurance in the system of vocational education and training]. Retrieved from http://ipq.org.ua/upload/files/files/03_Novyny/2015.03.18_Twinning_final_conference/ Quality\%20assurance-\%20UKR\%20.pdf [in Ukrainian].

Maiorov, A. N. (2005). Monitoring v obrazovanii [Education Monitoring]. Moskva: Intel-lektTcentr [in Russian].

Natsionalna stratehiia rozvytku osvity v Ukraini na 2012-2021 roky [National strategy for the development of education in Ukraine for 2012-2021]. Retrieved from http://oneu.edu.ua/wp-content/uploads/2017/11/nsro_1221.pdf [in Ukrainian].

Skubashevska, O. (2008). Monitorynh yakosti osvity: poniattia ta realnist zdiisnennia [Monitoring of livelihood: understanding and reality of health]. Vyshcha osvita Ukrainy [Higher education in Ukraine], 3, 37-42 [in Ukrainian].

Stefanovskaia, T. A. (1998). Pedagogika: nauka i iskusstvo: kurs lektcii [Pedagogy: science and art lecture course. Tutorial for students, teachers, graduate students]: ucheb. posob. dlia stud., prepodavatelei, aspirantov. Moskva: Sovershenstvo [in Russian].

Shishov, S. E., Kalnei, V. A. (2000). Shkola: monitoring kachestva obrazovaniia [School: monitoring the quality of education]. Moskva: Pedagogicheskoe obshchestvo Rossii [in Russian]. 


\section{ORGANIZATION OF MONITORING RESEARCH ON THE QUALITY OF EDUCATION IN VOCATIONAL (VOCATIONAL AND TECHNICAL) EDUCATIONAL INSTITUTIONS}

\section{Liudmyla Beberina Ihor Savenko}

The article considers the relevant issues of current state of development of vocational educational system in Ukraine in the conditions of European integration. An important task of training highly qualified specialists is to obtain complete and objective information about the state of education. In this regard, the problem of monitoring in the field of education is becoming more relevant, in particular, monitoring of professional training quality of graduates of vocational (technical vocational) educational institutions.

To ensure the quality of vocational (technical vocational) education in modern conditions, it is important to develop a system of internal evaluation of the quality of education in vocational (technical vocational) educational institutions, which should be aimed at assessing the quality of education in terms of the end results of educational institutions, in particular training of future qualified workers. Evaluation of professional training of graduates of vocational (technical vocational) educational institutions should be carried out through the monitoring of its five components (intellectual, activity, communicative, reflexive. professionally important qualities). Processing monitoring data on the basis of a qualimetric approach using factor-criterion models is proposed. The prospect of further research is to determine the organizational and pedagogical conditions for monitoring the quality of education in vocational (technical vocational) educational institutions.

Key words: vocational (technical vocational) educational institutions, qualimetric model, qualified workers, monitoring, educational activity, assessment of quality of education, professional training. 